\title{
RESULTS-BASED ANALYSIS OF STUDENTS' ACADEMIC PERFORMANCE IN ENGLISH UNDER DISTANCE LEARNING
}

\author{
Mariel Kristine M. Cortez
}

Article DOI: https://doi.org/10.36713/epra7488 DOI No: 10.36713/epra7488

\begin{abstract}
Using the descriptive research design, this study aimed to do a results-based analysis of online and modular distance learning of the students' academic performance in English on first and second quarter of school year 20202021 in Don Manuel Rivera Memorial National High School. The respondents of the study were composed of 50 Online Distance Learning (ODL) Students and 250 Modular Distance Learning (MDL) Students from Grades 7 to Grade 10 levels of Don Manuel Rivera Memorial National High School.

This is a descriptive study using the questionnaire as the main tool in gathering the data. The data gathered were treated using frequency distribution and percentage statistics, weighted mean, standard deviation, and T-test.

The mean level of parents' support to ODL students was 2.72 interpreted as "Moderately Supportive" indicates that parents are somehow extending additional support to their children in accomplishing the tasks given to them. On the other hand, the mean level of parents support to MDL students was 2.95 interpreted as "Moderately Supportive" indicates that only few parents extend their support to their children despite the awareness that their children have no direct contact to their subject teachers to give them assistance in understanding the lessons. This concludes that students under online distance learning gets more instructional support rather than the students under modular distance learning which gives a huge impact to their academic performances.
\end{abstract}

\section{INTRODUCTION}

As the COVID-19 pandemic hit the Philippines, the educational status of students has been shifted from face-to-face to distance learning modality, changing how learners acquire knowledge. Learners have been given the freedom to choose among the different distance learning modality in able to continue their studies. However, learners who have chosen modular distance learning modality (MDL) feels that they are lacking of teacher support due to less contact with their teachers, on the other hand, learners who have chosen online distance learning modality (ODL) sees it as an advantage for almost having direct contact from their teachers giving them real-time feedback from their performances and outputs.

With this kind of educational setup, the learners under these two distance learning modalities cause different impacts on their academic performances.
The disadvantages of the modular distance learning aspect include lack of personal contacts between the teacher and students, lack of contacts between students, problems with cheating and identification of students, lack of direct control, lack of students individual characteristics consideration. The negative impact of the isolation factor can also be attributed to a separate aspect of the practical skills development: the low level of practical skills formation and the inability to master some special disciplines, the lack of practical training. (Korolkov, 2020)

On the other hand, Anderson, 2004 stressed in his paper - Towards a theory of online learning that online distance learning leads to emergence of facilitation discourse which helps students to perform better than before. Encouraging learning through online devices, where instructor plays an active role in enabling learners to develop thought frameworks and 


\section{EPRA International Journal of Research and Development (IJRD)}

Volume: 6 | Issue: 7 | July 2021
- Peer Reviewed Journal promotes discourse between the two communication ends.

In Don Manuel Rivera Memorial National High School, learners were also given the chance to continue their learning through adapting the distance learning modalities, modular and online distance learning modalities, according from their ICT coordinator, 73\% of the learners' population has chosen MDL modality, and the rest have chosen ODL modality. Upon the first card viewing, parents from MDL are alarmed on the results reflected on their children's report cards due to the fact that they do not know how to help their children to keep up with their lessons, they are thinking that the reason behind this is the absence of teacher's guidance unlike the face-to-face classroom setup before the pandemic strikes. This is why the researcher aims to conduct a results-based analysis of online and modular distance learning to the students' academic performance in English on first and second quarter of school year 2020-2021 of Don Manuel Rivera Memorial National High School.

\section{METHODOLOGY \\ Participants}

The respondents of this study were the 300 randomly selected learners of Don Manuel Rivera Memorial National High School from Grade 7 to Grade 10 of S.Y. 2020-2021. The respondents of this study are grouped into two, (50) fifty Online Distance Learners and (250) two hundred fifty Modular Distance Learners.

Instruments

A survey questionnaire was used in the data gathering procedure. The questionnaire consisted of five (5) parts; the first part consists of the personal profile of the respondents, the second part contains a frequency distribution of the respondents' availability of gadgets and internet connection, the third part contains the level of support given by the parents/guardians to the respondents.

\section{RESULTS AND DISCUSSION}

\section{A. Materials Used by Learners Under Online Distance} Learning

The data showing the materials used by the learners in online distance learning pertain to electronic gadgets like desktop computer, laptop, tablet, and Smart phone.

Table 1. Frequency Distribution on the Electronic Gadgets used by Online Distance Learners

\begin{tabular}{|l|c|c|}
\hline \multicolumn{1}{|c|}{ Gadgets } & Frequency & Percentage \\
\hline Desktop computer & 5 & $10 \%$ \\
\hline Laptop & 1 & $2 \%$ \\
\hline Tablet & 0 & $0 \%$ \\
\hline Smart phone & 25 & $50 \%$ \\
\hline Laptop \& Smart phone & 8 & $16 \%$ \\
\hline Desktop \& Smart phone & 3 & $6 \%$ \\
\hline Desktop, Laptop, \& Smart phone & 3 & $6 \%$ \\
\hline Desktop \& Tablet & 2 & $4 \%$ \\
\hline Tablet \& Smart phone & 2 & $4 \%$ \\
\hline Desktop, Laptop, Tablet \& Smart phone & 1 & $2 \%$ \\
\hline
\end{tabular}

The students were asked about the gadgets they use for online distance learning. Half of the students disclosed that they use Smartphone (50\%) for their online class. Only five of the students use desktop computer (10\%) while eight of them use laptop and Smartphone (16\%). Only a few of the students use desktop and smartphone or desktop, laptop and Smartphone (6\%).

This means that the students in ODL typically use Smartphone for their online class. There are only a few of them who use a combination of two or more electronic gadgets.
Gadgets play a vital role in the educational field in order to improve their skills and knowledge. It is very important for them since they need to improve their knowledge power to gain success in the future. Teachers can enhance their teaching skills and strategies also. In short, this technology is very important for both students and teachers but on the other hand, this technology has disadvantages too. Gadgets make the world a great and easy place to live. The growth of gadgets of ever-increasing difficulty opens new panorama for human ability. Gadgets 


\section{EPRA International Journal of Research and Development (IJRD)}

Volume: 6 | Issue: 7 | July 2021

provide a secure, at ease and well-nourished life for billions of human beings. People need advanced technology to stay active and strong. (Perfect Writers Hub, 2021).

Once students own a gadget, they have a chance to make their learning more enjoyable. Digital devices provide access to various closed online training platforms. Students, regardless of distances, can efficiently study in universities, or on online courses on
- Peer Reviewed Journal
Udemy, EdX, Teachable, Coursera, or other online platforms. (Vinsji, 2020)

As the learners use electronic gadgets in online distance learning, they were also asked about their internet connection. Their internet connection is categorized as Fiber internet, cable internet, broadband internet and cellphone data.

Table 2. Frequency Distribution on the Internet Connectivity used by Online Distance Learners

\begin{tabular}{|l|c|c|}
\hline Internet Provider Type & Frequency & Percentage \\
\hline Fiber Internet & 26 & $52 \%$ \\
\hline Cable Internet & 3 & $6 \%$ \\
\hline Broadband Internet & 3 & $6 \%$ \\
\hline Cellphone Data & 13 & $26 \%$ \\
\hline Fiber \& Broadband & 1 & $2 \%$ \\
\hline Fiber \& Converge & 1 & $2 \%$ \\
\hline Fiber \& Cellphone Data & 1 & $2 \%$ \\
\hline Fiber \& Cable & 2 & $4 \%$ \\
\hline
\end{tabular}

The respondents were asked about the type of internet provider they use for online distance learning. More than half of the online distance learners $(52 \%)$ use fiber internet for their online classes. Another big portion $(26 \%)$ of the online distance learners depend mainly on their cellphone data as internet provider to be used for their online classes. The rest of the online distance learners use a combination of other types of internet provider.
This means that most online distance learners have a stable and strong internet bandwidth that could support their online classes which could result to no connection interruption which could help the learners firmly cope up and follow the lessons.

\section{B. Learners' Attendance in Online Class}

The data showing the frequency of attendance of the online distance learners in English online classes.

Table 3. Frequency Distribution on the Students' Attendance in Online Class

\begin{tabular}{|l|c|c|}
\hline Attendance & Frequency & Percentage \\
\hline Always & 31 & $62 \%$ \\
\hline Often & 5 & $10 \%$ \\
\hline Occasionally & 7 & $14 \%$ \\
\hline Seldom & 7 & $14 \%$ \\
\hline Never & 0 & $0 \%$ \\
\hline
\end{tabular}

The respondents were asked on how often they attend their online class in English Subject. More than half $(62 \%)$ of the respondents answered that they "always" attend the online class and never missed a lesson. However, there were $14 \%$ of the respondents who just "seldom" attend their online class as well as the other $14 \%$ of the respondents who "Occasionally" attend their online class. On the other hand, $10 \%$ of the respondents "Often" attend their online classes and none $(0 \%)$ of the respondents answered that they have "Never" attended their online class.

This means that most of the online distance learners are active in attending their online class for their English subject which could lead to better understanding of the lessons.

(Rapposelli, J.A., 2014) stressed in his research, "The Correlation Between Attendance and Participation with Respect to Student Achievement in an Online Learning Environment" that there is a positive relationship between student attendance and participation and student final grade achievement similar to the previous research conducted by Nichols, 2003; Roby, 2004; Snell \& Mekies, 1995. 


\section{EPRA International Journal of Research and Development (IJRD)}

Volume: 6 | Issue: 7 | July 2021

- Peer Reviewed Journal

\section{Parents' Support to Learners}

The data showing the level of support given by the parents to their children during distance learning.

Table 4. Extent of Parents' Support to Learners

\begin{tabular}{|c|c|c|c|c|c|c|c|}
\hline \multirow{2}{*}{\multicolumn{2}{|c|}{ My parents/ guardians ... }} & \multicolumn{3}{|c|}{ Online } & \multicolumn{3}{|c|}{ Modular } \\
\hline & & Mean & SD & V.I. & Mean & SD & V. I. \\
\hline \multicolumn{2}{|c|}{$\begin{array}{l}\text { 1. is/are doing tutorials for me to } \\
\text { understand the lessons presented in the } \\
\text { modules/ activities }\end{array}$} & 2.72 & 1.278 & MS & 2.98 & 1.395 & MS \\
\hline \multicolumn{2}{|c|}{$\begin{array}{l}\text { 2. is/are helping me in answering my } \\
\text { modules/ activities. }\end{array}$} & 2.38 & 1.176 & SS & 2.64 & 1.391 & MS \\
\hline \multicolumn{2}{|c|}{$\begin{array}{l}\text { 3. is/are giving additional explanations } \\
\text { about the topics. }\end{array}$} & 2.66 & 1.239 & MS & 2.82 & 1.357 & MS \\
\hline \multicolumn{2}{|c|}{$\begin{array}{l}\text { 4. is/are checking/reviewing my work } \\
\text { once I finish them. }\end{array}$} & 2.84 & 1.251 & MS & 3.18 & 1.487 & MS \\
\hline \multicolumn{2}{|c|}{$\begin{array}{l}\text { 5. is/are suggesting revisions on my } \\
\text { answers to achieve quality output. }\end{array}$} & 2.98 & 1.253 & MS & 3.10 & 1.430 & MS \\
\hline \multicolumn{2}{|c|}{ Overall Mean } & \multicolumn{3}{|c|}{$\begin{array}{c}2.72 \\
\text { Moderately Supportive }\end{array}$} & \multicolumn{3}{|c|}{$\begin{array}{c}2.95 \\
\text { Moderately Supportive }\end{array}$} \\
\hline Legend & Range & \multicolumn{6}{|c|}{ Verbal Interpretation } \\
\hline 5 & $4.20-5.00$ & \multicolumn{6}{|c|}{ Highly Supportive (HS) } \\
\hline 4 & $3.40-4.21$ & \multicolumn{6}{|c|}{ Supportive (S) } \\
\hline 3 & $2.60-3.39$ & \multicolumn{6}{|c|}{ Moderately Supportive (MS) } \\
\hline 2 & $1.80-2.59$ & \multicolumn{6}{|c|}{ Slightly Supportive (SS) } \\
\hline 1 & $1.00-1.79$ & \multicolumn{6}{|c|}{ Unsupportive (US) } \\
\hline
\end{tabular}

The parents are expected to provide support to their children by doing some tutorials in the activities presented in the learning materials. The students under ODL $(M=2.72, \quad S D=1.278)$ and MDL $(M=2.98$, $S D=1.395)$ gained moderate support from their parents in terms of tutorials. The students in the ODL modality gained slight support from their parents when it comes to answering the activities in the modules $(M=2.38$, $S D=1.176)$ while those under MDL obtained moderate support from their parents $(M=2.64, S D=1.391)$.

The overall mean of 2.72 revealed that the parents of the students under ODL provide moderate support to their children. Likewise, those under MDL gained moderate support from their parents as shown by the overall mean of 2.95 . This means that the parents of online distance learners depend mainly on the instructional support given by the teachers to their children that is why parents of ODL just give only moderate parental instructional support.

Tapor, D. R., et.al., (2011) stressed in their study that parent involvement in a child's education is consistently found to be positively associated with a child's academic performance. A multiple mediation model indicated that the child's perception of cognitive competence fully mediated the relation between parent involvement and the child's performance on a standardized achievement test. The quality of the student-teacher relationship fully mediated the relation between parent involvement and teacher ratings of the child's classroom academic performance. Limitations, future research directions, and implications for public policy initiatives were discussed.

In a study by Faizi (2018), teachers tend to have better teaching proficiency while tutoring students using Web 2.0 mobile technologies, this also led development of positive students' learning perceptions. In todays' world, instructors prefer to incorporate interactive teaching pedagogy while actively working with technological devices that truly serve to promote blended and broadcasted learning (Hamm et al., 2013). Mobile technology is being used as a cutting edge technology for enabling the HEIs to deliver real time lectures to students, thus, realizing the real need of encouragement and assistance provided by the instructors for effective understanding (Pedro, de 


\section{EPRA International Journal of Research and Development (IJRD)}

Volume: 6 | Issue: 7 | July 2021
- Peer Reviewed Journal
Oliveira Barbosa, \& das Neves Santos, 2018; Reinders $\&$ Benson, 2017).The prime purpose of bringing blended learning into teaching methodology is to make learning environment more discussion-centered, interactive and encourage prompt feedback (Isbell, Rawal, Oh, \& Loewen, 2017; Reinders \& Benson, 2017). This helps students become more prudent in evaluating and diagnosing a particular situation (Sha, Looi, \& Chen, 2012; Cho, Lee, \& Jonassen, 2011).
D. Time Spent by Learners in Answering the Modules

The data showing the speed of time spent by learners in accomplishing the tasks and activities in their modules.

Table 5. Time Spent by Students in Accomplishing the Tasks and Activities in their Modules

\begin{tabular}{|c|c|c|c|c|c|c|}
\hline \multirow{2}{*}{ The students ... } & \multicolumn{3}{|c|}{ Online } & \multicolumn{3}{|c|}{ Modular } \\
\hline & Mean & S.D. & V. I. & Mean & S.D. & V. I. \\
\hline $\begin{array}{l}\text { 1. finish reading my English modules on } \\
\text { time }\end{array}$ & 3.54 & 1.199 & F & 3.78 & 1.274 & $\mathrm{~F}$ \\
\hline $\begin{array}{l}\text { 2. complete particular tasks/activities on } \\
\text { my modules on time (based on the } \\
\text { Weekly Home Learning Plan) }\end{array}$ & 3.82 & 1.224 & F & 3.74 & 1.324 & $\mathrm{~F}$ \\
\hline $\begin{array}{l}\text { 3. finish my English modules/ tasks/ } \\
\text { activities on time (based on the Weekly } \\
\text { Home Learning Plan) }\end{array}$ & 3.94 & 1.096 & F & 3.82 & 1.292 & $\mathrm{~F}$ \\
\hline $\begin{array}{l}\text { 4. submit my modules/activities on time } \\
\text { (based on the retrieval schedules) }\end{array}$ & 3.84 & 1.235 & $\mathrm{~F}$ & 4.26 & 1.338 & $\mathrm{EF}$ \\
\hline Overall Mean & \multicolumn{3}{|c|}{$\begin{array}{l}3.79 \\
\text { Fast }\end{array}$} & \multicolumn{3}{|c|}{$\begin{array}{l}3.90 \\
\text { Fast }\end{array}$} \\
\hline
\end{tabular}

$\begin{array}{ll}\text { Legend } & \text { Range } \\ 5 & 4.20-5.00 \\ 4 & 3.40-4.21 \\ 3 & 2.60-3.39 \\ 2 & 1.80-2.59 \\ 1 & 1.00-1.79\end{array}$

Verbal Interpretation
Extremely Fast $(E F)$
Fast $(F)$
Moderately Slow $(M S)$
Slow $(S)$
Extremely Slow $(E S)$

The respondents were asked about the span of time they spend in accomplishing the tasks and activities on their modules. Both online distance learners and modular distance learners were able to accomplish the tasks and activities on their modules in "Fast" speed having a 3.79 overall mean of the $\mathrm{ODl}$ and 3.90 overall mean of the MDL.
This means, learners under MDL are accomplishing their tasks and activities on their modules faster than the ODL.

\section{E. Level of Learners' Academic Performance}

The data showing the level of learners' quarterly academic performance in English during the first and second quarter of the school year 2020-2021. 


\section{EPRA International Journal of Research and Development (IJRD)}

Volume: 6 | Issue: 7 | July 2021

- Peer Reviewed Journal

Table 6. Level of Learners' Academic Performance

\begin{tabular}{|l|c|c|c|c|c|c|c|c|}
\hline \multirow{2}{*}{ Grades } & \multicolumn{4}{|c|}{ Online Distance Learning } & \multicolumn{4}{c|}{ Modular Distance Learning } \\
\cline { 2 - 9 } & $\mathbf{1}^{\text {st }}$ Quarter & \multicolumn{2}{|c|}{$\mathbf{2}^{\text {nd }}$ Quarter } & \multicolumn{2}{|c|}{$\mathbf{1}^{\text {st }}$ Quarter } & \multicolumn{2}{|c|}{$\mathbf{2}^{\text {nd }}$ Quarter } \\
\cline { 2 - 9 } & $\mathbf{f}$ & $\mathbf{\%}$ & $\mathbf{f}$ & $\mathbf{\%}$ & $\mathbf{f}$ & $\mathbf{\%}$ & $\mathbf{f}$ & $\mathbf{\%}$ \\
\hline $\begin{array}{l}90-100 \\
\text { (Outstanding) }\end{array}$ & 4 & $8 \%$ & 12 & $24 \%$ & 23 & $9.2 \%$ & 25 & $10 \%$ \\
\hline $\begin{array}{l}85-89 \\
\text { (Very Satisfactory) }\end{array}$ & 28 & $56 \%$ & 34 & $68 \%$ & 83 & $33.2 \%$ & 103 & $41.2 \%$ \\
\hline $\begin{array}{l}80-84 \\
\text { (Satisfactory) }\end{array}$ & 18 & $36 \%$ & 4 & $8 \%$ & 128 & $51.2 \%$ & 107 & $42.8 \%$ \\
\hline $\begin{array}{l}75-79 \\
\text { (Fairly Satisfactory) }\end{array}$ & 0 & $0 \%$ & 0 & $0 \%$ & 12 & $4.8 \%$ & 10 & $4 \%$ \\
\hline $\begin{array}{l}\text { Below 75 } \\
\text { (Did Not Meet Expectations) }\end{array}$ & 0 & $0 \%$ & 0 & $0 \%$ & 4 & $1.6 \%$ & 5 & $2 \%$ \\
\hline
\end{tabular}

During the first quarter, more than half of the students under the ODL showed very satisfactory performance $(56 \%)$. There was an increase in the students' performance during the second quarter, as 34 students $(68 \%)$ belong in the very satisfactory range. None of the students under the ODL had a grade lower that 80 , both in the first and second quarter. This indicates that the students under the ODL get adequate instructional support from both the teachers and their parents.

Philippine Information Agency (2020) shares that the guidance and support of the parents will serve as an inspiration for the children to study. Studies revealed that in this educational set-up such as modular distance learning, the missing link in educational equity is parental participation. Schools and teachers, even the most established ones, cannot simply educate every child on their own. Dynamic support from parents and family is needed (Colombo, 2006).
When parents and children collaborate in learning activities, bonding between parents and children increases as they are able to spend much more time together. Such instances allow parents to become a source of comfort in easing pain and worry and engage in conversations with their children to help them in alleviating their anxiety. It has been recommended that parents should be taught interventions on how to provide emotional support to children at times of uncertainty (Wang, Zhang, Zhao, Zhang, \& Jiang, 2020). Online schooling system with parental support guidelines could help in improving the bond between children and their parents.

\section{F. Difference in the Learners' Academic Performance The data showing the difference of Online and Modular distance learners' quarterly academic performance in English during the first and second quarter of the school year 2020-2021.}

Table 7. Difference in the Learners' Academic Performance

\begin{tabular}{|c|c|c|c|c|c|c|}
\hline \multicolumn{2}{|c|}{ Mean } & \multirow{2}{*}{ Mean Difference } & $\boldsymbol{t}$-value & $\begin{array}{c}\text { Critical } \\
\text { Value }\end{array}$ & p-value & Analysis \\
\cline { 1 - 2 } Modular & Online & 4.17 & -4.098 & 1.649 & 0.000 & Significant \\
\hline 83.75 & 87.92 & &
\end{tabular}

The students exposed to ODL and MDL showed varying performances based on their first quarter and second quarter grades. A significant difference was noted on the students' first quarter grades $(t=2.402$, $p=0.017)$. Likewise, there was a significant difference on their grades in the second quarter $(t=2.402$, $p=0.017$ ).

This means that the students under the ODL get profound parental and teacher instructional support which affects their academic performance. In addition, going back to the results shown on table 5, although the modular distance learners gathered a faster speed (overall mean 3.90) in accomplishing the tasks and activities on their modules doesn't connote that they have a quality-accomplished modules because they lack both parental and teacher instructional support which only shows that they just quickly accomplish it only for the sake of meeting the deadline. 


\section{EPRA International Journal of Research and Development (IJRD)}

Volume: 6 | Issue: 7 | July 2021
- Peer Reviewed Journal

4. Korolkov, A. (2020). Advantages and Disadvantages of Distance Learning on Students' and

Teachers' of the Physical Culture Faculty Opinion

5. Perfect Writers Hub, (2021) https://www.perfectwriters.co.uk/blog/advantagesand-disadvantages-of-gadgets-for students/\#: :text=Gadgets\%20play\%20a\%20vital $\% 20$ role, gain\%20success\%20in\%20the\%20future. $\&$ text $=$ Gadgets $\% 20$ provide $\% 20$ a $\% 20$ secure $\% 2 \mathrm{C} \%$ 20at,for\%20billions\%20of\%20human\%20beings.

6. Philippine Information Agency. (2020, October 9). Teaching-learning modality under the new normal. https://pia.gov.ph/features/articles/10 55584

7. Rapposelli, J.A. (2014). The correlation between attendance and participation with respect to student achievement in an online learning environment ( $p$. vi) Liberty University

8. Tapor, D. R. et.al., (2011) Parent involvement and student academic performance: A multiple mediational analysis

9. Vinsji, M. (2020). The Importance of Digital Gadgets for Students and Their Educational Achievements

10. Wang, G., Zhang, Y., Zhao, J., Zhang, J., \& Jiang, F. (2020). Mitigate the effects of home confinement on children during the COVID-19 outbreak. The Lancet, 395(10228), 945-947. from their parents for add
B. Parents and school:

1. Parents/guardians are advised to devote a little more time to support and guide their children in accomplishing tasks and activities on their modules.

2. Parents/guardians are encouraged also to assist their children by doing remediation through the use of various learning support materials like selflearning modules provided by the school and other sources of information from different educational platforms offered by the Department of Education.

3. The school may consider shifting the learners from modular distance learning to online distance learning by providing the learners free internet (Mobile Data) instead of spending too much on printed materials.

\section{REFERENCES}

1. Anderson, T. (2004). Towards a theory of online learning. In T. Anderson (Ed.), Theory and Practice of Online Learning (Vol.2, pp. 109-119). Athabasca University Press.

2. Colombo, M. W. (2006). Building school partnerships with culturally and linguistically diverse families. Phi Delta Kappan, 2, 314-318.

3. Faizi, R. (2018). Moroccan higher education students' and teachers' perceptions towards using Web 2.0 technologies in language learning and teaching. Knowledge Management \& E-Learning, 10(1), 86-96. 